\title{
From high-flying hero to eugenics advocate
}

\author{
The Immortalists: Charles Lindbergh, \\ Dr. Alexis Carrel, and Their Daring Quest \\ to Live Forever \\ David M. Friedman \\ Ecco/HarperCollins Publishers; 2007. \\ 338 pp $\$ 26.95$
}

I will never forget how inspired I felt when, around the age of $8, \mathrm{I}$ first saw the film The Spirit of St. Louis, depicting Charles Lindbergh on his dramatic transatlantic flight. And I will never forget how betrayed I felt upon learning a bit later in life that the famous aviator had also been a womanizer, eugenicist and an unrepentant admirer of Hitler and Nazism.

In reading this book, I learned that in addition to his pernicious politics, Lindbergh also had a bent toward what we now call bioengineering. In the 1920s, frustrated by medicine's inability to help his sister-in-law, who suffered from a damaged cardiac valve, he turned to one of the most famous men of his day, Dr. Alexis Carrel, a French surgeon who had been awarded the Nobel Prize in 1912 for his pioneering work on vascular anastomosis.

This fascinating book tells the tale of their unusual friendship and fruitful scientific collaboration on organ perfusion, work constituting an important early step toward the whole body bypass necessary for open cardiac surgery.

The problem is not with their science, which was sound, but rather with their ultimate goals. Both believed that through this work they could ultimately defeat death and ensure the individual's immortality. Being staunch eugenicists, the men also held that these medical breakthroughs should be restricted for use by the "white race." As Carrel put it, and Lindbergh concurred, "There is no escaping the fact that men are not created equal, as democracy, invented in the 18th century - when there was no science to refute it - would have us believe." Carrel went on to offer

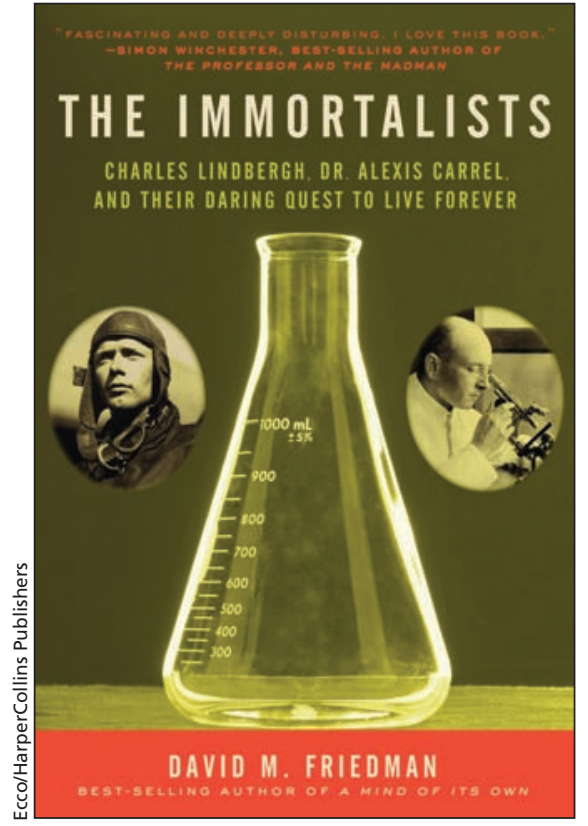

that the human race is pushed forward by "the elite." He felt it unfortunate that "we don't yet understand the genesis of great men. Perhaps it would be effective to kill off the worst [of us] and keep the best, as we do in the breeding of dogs."

Although their views were extreme, they were not unique at the time; many people in Canada, the United States and most European countries held similar beliefs (CMAJ 2008;179:259-60). Alberta and British Columbia, for example, had eugenic laws on the books that were not repealed for another 40 years.

In addition to his eugenic beliefs, Lindbergh also admired the social and political policies of Hitler and the Nazi party. He visited Germany several times in the 1930s and proudly received a swastika-shaped and jewel-encrusted award, the Verdienstkreuz Deutscher Adler ("service cross of the German eagle"), beneficently bestowed upon him by his aviator colleague Hermann Göring, one of Hitler's henchmen.

During a visit to Germany in 1936, Lindbergh wrote enthusiastically to Carrel: "I believe that Germany is in many ways the most interesting place in the world today, and some of the things I see here encourage me greatly."

After World War II, Lindbergh remained unapologetic for his war-time stance. Friedman points out that Lindbergh's Wartime Journals (1970) “contained passages that seemed indifferent to the regimented brutality of Hitler's Nazi Germany, and some passages that seemed clearly anti-Semitic."

Naturally, this whole story makes me most uncomfortable, both as as a Jew and as a geriatrician.

Much of Carrel and Lindbergh's scientific work was an attempt to defeat death and above all, to conquer aging — something many in my field still talk about today.

On the one hand we have the likes of Dr. Aubrey de Grey, who believes we can (and should) live for hundreds of years, if not forever. On the other, fortunately, there are the more thoughtful voices such as that of Leon Kass, a member of the United States President's Commission on Ethics, who warns of the known and perhaps more important, the yet unknowable social and psychological burdens that extreme longevity might bring upon us.

I have long felt an ill-defined sense of discomfort when I read about or listen to those who want to extend life "forever." I had thought, at least until now, that I was concerned by the kinds of worries raised by Kass and other social critics. After reading this fascinating book, I realise that quests for immortality can sometimes hide more pernicious and even malevolent drives.

\section{A. Mark Clarfield MD \\ Department of Geriatrics \\ Soroka Hospital \\ Ben-Gurion University of the Negev \\ Beer-Sheva, Israel}

Dr. Clarfield was previously the head of Geriatrics at the Sir Mortimer B.

Davis-Jewish General Hospital, McGill University, Montréal, Que. 